\title{
Macroeconomic performance of the Czech Republic during the global pandemic crisis
}

\author{
Jolana Volejnikova ${ }^{1, *}$, Ondrej Kuba ${ }^{1}$ \\ ${ }^{1}$ University of Pardubice, Faculty of Economics and Administration, Department of Economic \\ Sciences, Studentska 84, 53210 Pardubice 2, Czech Republic
}

\begin{abstract}
Research background: The global SARS-CoV-2 pandemic is unprecedented for human society. Despite the continuing uncertainty about the future, it is certain that the global consequences of the pandemic will have many dimensions. Among others, the economic impacts are extremely significant. However, the sudden slowdown in economic activity, the declared quarantines, and the state of emergency have many specific impacts in individual countries. The Czech economy (as well as other countries in the world) was exposed to an unexpected exogenous shock. The data confirm that, in 2020, the decline in the performance of the Czech economy was the deepest in its history.

Purpose of the article: The primary goal of this article is to analyze the macroeconomic performance of the Czech Republic during a pandemic crisis. However, we also research the impact of the pandemic on individual sectors of the national economy in the context of government measures.

Methods: The analytical part of the article is processed on the basis of publicly available statistical data, economic analyses, and economic forecasts of renowned institutions. The derivation and argumentation of the conclusions are based on an empiric-inductive approach, methods of synthesis, and comparison.

Findings and value added: The article maps the direct and mediated macroeconomic effects of the pandemic crisis in the reality of the Czech Republic. At the theoretical level, the aim of the article is to bring new knowledge to current economic theory, especially in the field of macroeconomics and sectoral analysis as well as the theory of public choice.
\end{abstract}

Keywords: globalization; SARS-CoV-2; macroeconomics; government action; Czech Republic.

JEL Classification: $E 1 ; P 42 ; P 44$

${ }^{*}$ Corresponding author: jolana.volejnikova@,upce.cz 


\section{Introduction}

The Covid-19 pandemic has plunged the world economy into a deep and globally synchronized crisis. Many companies, households, and even sectors of the economy have found themselves facing enormous, literally existential uncertainties overnight. The governments of countries throughout the world were forced to intervene very quickly and forcefully. At the same time, they had to decide whether to prioritize the medical or economic aspects of the measures taken. Globally, society was confronted with a completely unprecedented phenomenon that no one had anticipated or had lived through or experienced (Klaus, 2020, Caligiuri et al., 2020, Liu et al., 2020).

Compared to Italy or Spain, the Czech Republic was one of the less affected countries in the first wave of the pandemic (spring 2020). The first cases of the disease were verified on March 1, 2020, when people were returning from foreign ski trips. In response to the situation, the government announced the first lockdown, which was canceled on 18 May 2020. In total, the adopted anti-pandemic measures affected almost two-fifths of the Czech economy. After easing the situation in the summer months, the government announced another lockdown in the autumn, which - in connection with the second and subsequent winter wave of the pandemic (with varying intensity of severity of measures) - lasted from October 2020 to June 2021. In the first week of September, the Czech Republic ranked among the most affected countries in Europe in terms of the number of newly infected individuals per million inhabitants, and at the threshold of 2021 it was even described as the most affected country in the world by a pandemic. The Czech Republic also sadly occupied first place within the European Union (EU) in terms of the average over-mortality of the population. From March 2020 to March 2021, this rate was 13\% in the Eurozone whereas, in the Czech Republic, this value was more twice that amount.

It is difficult to find a historical comparison for the current pandemic crisis, although the interest in theoretically elucidating the causes of economic crises is one of the key topics of general economics (Smith et al., 2019, Takahashi, 2020). It is already evident in the works of the classical school of political economy, yet the beginnings of modern theories of economic cycles are associated with the work of the Frenchman Clement Juglar and his work "Des crises commerciales et de leur retour périodique en France" (1862). A detailed overview of alternative theories of economic cycles together with their classification has been presented, for example, by Haberler (1937). Monetary causes have been related to the monetary policy of central banks, the regulation of the amount of money or fluctuations in interest rates (J. K. Wicksell, L. von Mises, R. G. Hawtrey, M. Friedmann, etc.), real causes (J. M. Clark, F. A. Hayek, A. Spiethoff, R. J. Barro, A. Aftalion, etc.), or their various combinations. Keynesian approaches (P. A. Samuelson, J. R. Hicks, F. Modigliani, M. Kalecki, etc.) have emphasized the fluctuation of aggregate demand, mainly due to investment instability (Broer, 2019, Rancan, 2020); meanwhile, classical theories have turned their attention to shocks to the side of the aggregate supply in the context of real variables (so-called real economic cycle theory; e.g., D. Romer, R. E. Lucas, G. D. Hansen, E. C. Prescott, F. E. Kydland). Since the middle of the last century, the importance of theories of the political economic cycle has been growing, which presupposes the existence of a political market and the government's ability to manipulate the economy (W. D. Nordhaus, D. A. Hibbs, A. Alesina, K. Rogoff, A. Sibert, T. Persson, G. Tabellini, etc.). Today, models of endogenous growth (P. Romer, R. E. Lucas, etc.), working with the assumption of endogeneity of technological changes, innovations, human capital, knowledge, and the effects of their spillover, are also coming to the forefront of scientific interest. Petricevic and Teece (2019), Cai (2019), and the theory of the so-called equilibrium cycle (R. E. Lucas, etc.) have integrated the cycle into the theory of economic equilibrium, including its explanation in the context of rational expectations. 
Current research points to a number of other factors that either directly or indirectly affect the efficiency of production resources and the performance of economies (e.g., Falk et al., 2018, Mitchell, 2020). In the context of the subject of our article, it must be stated that the study of the impact of the SARS-CoV-2 global pandemic on the economic performance of countries is only in its infancy (Dobrowolski, 2020, Mishra, 2020, Deb et al., 2020). Our article is primarily focused on the analysis of the economic consequences of the pandemic crisis in the reality of the Czech Republic. Its aim is to analyze in particular the macroeconomic impacts of the pandemic, their specifics, and the expected probable development. We focus on key indicators of macroeconomic performance of economies: gross domestic product (GDP), employment of the population, the development of the price level, and the foreign balance. At the theoretical level, the article aims to bring new knowledge to theories of economic crises.

\section{Methods}

The elaboration of the research problem consists of both a systematic search of the professional literature (review) and a thorough analysis, comparison, and synthesis of available statistical data. The theoretical analysis is based on the selection of key findings, especially in macroeconomics and public economics. Its backbone is the original work of the cited authors, supplemented by knowledge based on a search of relevant sources of professional global and domestic literature. The acquired knowledge is compared in the context of theoretical-methodological and historical genesis, and the methods of a comparative opinion analysis, synthesis, and verbal deduction are applied here. Emphasis is placed on defining the key determinants of economic crises. The research is conducted using the desk research method. The analytical part of the article is carried out using publicly available statistical data, economic analyses, and economic forecasts. As a source of data, we mainly used databases from the Czech Statistical Office (CSO) and the Czech National Bank (CNB), the Eurostat database, and officially published data from ministries (especially the Ministry of Health and the Ministry of Finance). The subject of the analysis is data (macroeconomic indicators) from 2020. Complete data from the second quarter of 2021 are currently available and were calculated using year-on-year chained indices of data expressed in the previous year's prices. To solve the research problem, the applied methods complement and combine with each other, enabling overlap and synergy of the final output. We base the derivation and argumentation of the conclusions on an empirical-inductive approach, methods of analysis, comparison, and synthesis. We further focus on defining the key characteristics of the ongoing pandemic crisis, which we connect with economic theory and develop to the level of general conclusions. Their definition and concretization open up space for scientific controversy and further research.

\section{Results and Discussions}

As shown in the following chart (Fig.1), the Czech economy has long grown above the EU average. The year-on-year real GDP growth rates on the chart show the cyclical fluctuations of the economy, with the highest growth to date in 2006, when the real GDP growth rate reached $6.8 \%$ year on year. On the other hand, the Czech economy showed the deepest decline in $2009(-4.7 \%)$ due to the global financial and economic crisis. As is clear from the chart, the period before the outbreak of the pandemic crisis was relatively successful for the Czech economy. This was the result of an exceptionally favorable economic situation at the peak of the economic cycle, which was associated with the economy overheating above its potential. At that time, this situation already signaled a future decline in economic performance due to low labor productivity, the lagging of innovation processes, and 
deepening imbalances in the sub-markets, especially in the labor market. Before the arrival of the Covid-19 pandemic, the Czech economy had slowed down, and all indications were that growth would have stopped even without the outbreak. However, unemployment was still very low $(2.0 \%)$, and the number of job vacancies even exceeded the number of jobseekers. The Czech economy thus entered the coronavirus crisis with an overheated labor market, which was reflected in, among other things, the relatively high inflation exceeding the upper limit of the CNB's inflation target (2\%). At the end of 2019, the official estimate of economic development for 2020 was only $2 \%$.

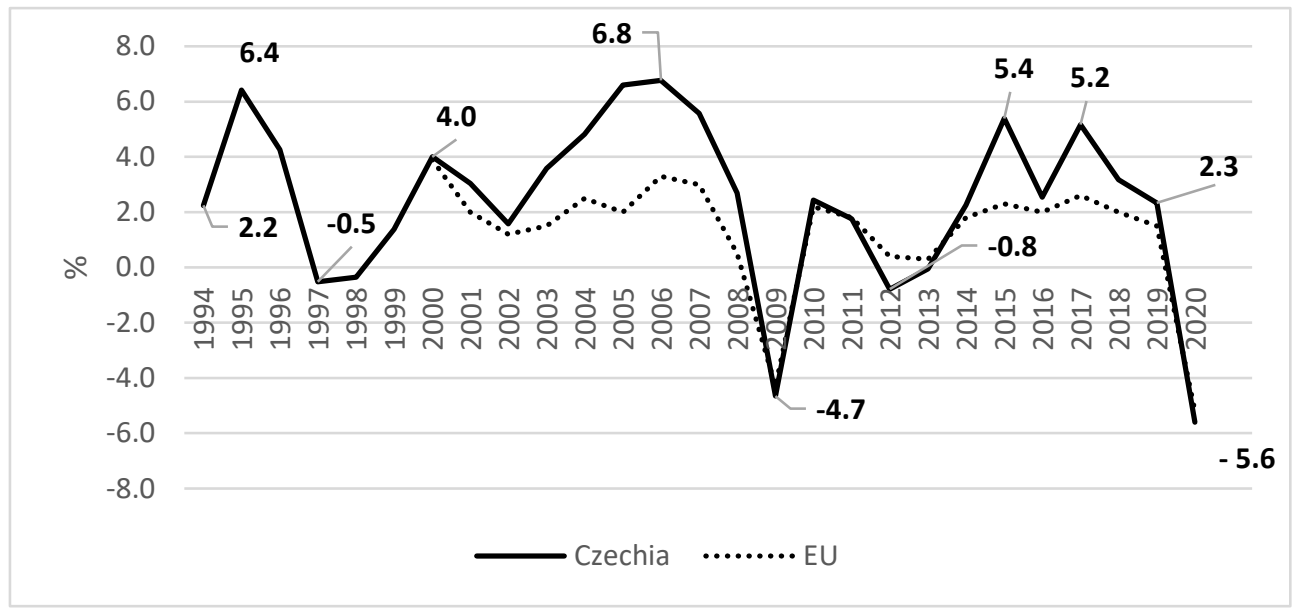

Figure 1. Year-on-year real GDP growth rate in \%

Source: [CSO], own adjustments

The economic consequences of the pandemic crisis were already evident in the data from the first quarter of 2020 and signaled a deep economic downturn. The first estimates of the economic downturn ranged from $7.5 \%$ to $8.4 \%$. On the supply side, there was a significant decline in potential output and national labor productivity; a disruption to supplier-customer relations, including cross-border contacts; an outage of foreign trade; a loss of foreign labor; and the closure or reduction of some companies. On the demand side, the uncertainty on the part of individual economic entities was associated with a preference for liquidity, a postponement of consumption in favor of savings, and a decline in investment. On the contrary, the resolution of the crisis has led to a sharp increase in general government expenditures. Expenditures on social benefits, subsidies, and capital transfers increased in particular, while revenues stagnated due to the economic slowdown and tax changes. Revenues decreased mainly in accommodations and food service activities (by more than $85 \%$ year-on-year), in subjects focusing on education, health services, various arts, leisure activities, and other personal services. The decline mainly concerns small and medium-sized enterprises, which represent an important market segment in the Czech economy. However, some sectors (especially IT companies, companies producing medical and protective equipment, pharmaceutical companies, retail e-shops, etc.) paradoxically strengthened the crisis. The key values of macroeconomic indicators in the observed period are shown in Table 1).

However, in comparison with the forecast, as well as with other EU member states, the economic downturn in the Czech Republic was not so deep. It recorded a value of $-5.6 \%$ while, for comparison, the smallest economic loss in the EU $(-2.9 \%)$ was recorded by Sweden and Finland $(-3.3 \%)$. In the EU, only Spain $(-11 \%)$ and Italy $(-10.6 \%)$ exceeded the limit of 
the decline in growth of more than $10 \%$. For the European Union, GDP growth of $7.3 \%$ decreased (for comparisons, the USA $-3.5 \%$ and the United Kingdom $-10.7 \%$ ). The only economy with positive growth was China $(2.1 \%)$, which became the driving force behind the global recovery in the second half of 2020 thanks to strong state support.

Table 1. Key macroeconomic indicators

\begin{tabular}{|l|c|c|c|}
\hline & 2019 & 2020 & 2021 \\
\hline $\begin{array}{l}\text { GDP (\%, y-o-y, real terms, seas. } \\
\text { adjusted) }\end{array}$ & 3.0 & 5.8 & $\left.7.8^{*}\right)$ \\
\hline $\begin{array}{l}\text { Household consumption (\%, y-o-y, } \\
\text { real terms, seas. adjusted) }\end{array}$ & 2.6 & -7.1 & $\left.3.9^{*}\right)$ \\
\hline $\begin{array}{l}\text { Government consumption (\%, y-o- } \\
\text { y, real terms, seas. adjusted) }\end{array}$ & 2.5 & 3.4 & $\left.3.6^{*}\right)$ \\
\hline $\begin{array}{l}\text { Gross fixed capital formation (\%, } \\
\text { y-o-y, real terms, seas. adjusted) }\end{array}$ & 4.5 & -10.2 & $\left.-3.6^{*}\right)$ \\
\hline $\begin{array}{l}\text { Industry (\%, sales, y-o-y growth } \\
\text { rate in nominal terms) }\end{array}$ & 1.1 & -6.1 & $\left.11.4^{* *}\right)$ \\
\hline $\begin{array}{l}\text { Construction (\%, sales, y-o-y } \\
\text { growth rate in nominal terms) }\end{array}$ & 2.7 & -6.2 & $\left.7.9^{* *}\right)$ \\
\hline $\begin{array}{l}\text { Services (\%, sales, y-o-y growth } \\
\text { rate in nominal terms) }\end{array}$ & 1.2 & -11.7 & $\left.13.8^{*}\right)$ \\
\hline $\begin{array}{l}\text { ILO general unemployment rate } \\
\text { (\%, average, seas. adjusted) }\end{array}$ & 2.0 & 2.6 & $\left.3.1^{*}\right)$ \\
\hline $\begin{array}{l}\text { Share of unemployed persons (\%, } \\
\text { average, seas. adjusted) }\end{array}$ & 2.8 & 3.51 & $\left.4.1^{*}\right)$ \\
\hline $\begin{array}{l}\text { Average monthly wage (\%, y-o-y, } \\
\text { real terms) }\end{array}$ & 5.0 & -0.1 & $\left.3.5^{*}\right)$ \\
\hline $\begin{array}{l}\text { Monetary policy-relevant inflation } \\
\text { (\%, y-o-y, average) }\end{array}$ & 2.8 & 3.2 & $2.8^{* *}$ \\
\hline $\begin{array}{l}\text { Current account/GDP (\%, nominal } \\
\text { terms) }\end{array}$ & 0.3 & 3.6 & $\left.3.5^{*}\right)$ \\
\hline State budget balance (mld. CZK) & -28.52 & 36.0 & $-320(\mathrm{design)}$ \\
\hline State debt/GDP (v \%) & $\begin{array}{l}\text { Government debt/GDP (\%, nominal } \\
\text { terms) }\end{array}$ & 30.6 & - \\
\hline
\end{tabular}

Source: [CSO], own adjustments

*) data for the 2nd quarter of 2021, year-on-year in $\%$

**) June 2021, percentage change compared to the same month of the previous year

The recession in the Czech economy was accompanied by an increase in unemployment, which shows not only strongly differentiated sectoral and regional development, but also gender development. The general unemployment rate according to the ILO definition in the 15-64 years age group (share of the unemployed in the labor force) increased by $0.6 \%$ yearon-year in 2020 to $2.6 \%$. The indicator reached its highest value in November 2020 (3.8\%), when 274,500 people were out of work. This was the statistically highest November value since 2016. In the second quarter of 2021, further growth in unemployment continued to the current value of $3.1 \%$. Note that, according to the ILO definition, unemployed persons re those who had no job during the reference period, did not work even one hour for wages or remuneration, and were actively looking for a job that they would be able to take up within two weeks at the latest. This methodology is uniform for all EU member states and provides 
internationally comparable data. At the national level, the focus is more on indicators based on labor office registers. Among others, it is the share of unemployed persons, which expresses the share of available jobseekers aged 15-64 among all inhabitants of the same age. The number of employees decreased by $1.3 \%$ year-on-year in 2020 . Currently (second quarter of 2021), the employment rate of the population is 57.6\%. Employment fell in all three sectors of the national economy. Although the primary sector recorded a year-on-year decrease in the number of employees by 8.3 thousand, the secondary sector decreased by as much as 27.5 thousand, mainly due to a decrease in the number of employees in the manufacturing industry. In the tertiary sector of services, total employment decreased by 5.7 thousand. The number of persons employed decreased in accommodations, food and beverage service activities, wholesale and retail trade, and repair of motor vehicles, transport, and storage as well as in administrative activities and in the public administration sector. On the other hand, employment in the services sector increased in the information and communication activities section, in education, and in finance and insurance.

Price stability in the Czech Republic is maintained by the CNB's monetary policy, which applies an inflation targeting regime. In it, it seeks to keep inflation close to the preannounced target. Since 2010, it has taken the form of a year-on-year increase in the consumer price index of $2 \%$, with a tolerance band of \pm 1 percentage point. The goal at this level corresponds to the practice of advanced economies. The average inflation rate for 2020 was $3.2 \%$, which means an increase of $0.4 \%$ compared to 2019 . This was the highest value since 2012. The rise in prices was mainly due to the rise in prices of food, beverages, and tobacco and housing prices. Meanwhile, a decline was recorded in fuel prices in connection with the drop in oil prices and the slowdown in the world economy. As a result of the fall in domestic demand, the so-called core inflation (a change in the current price level adjusted for food and energy prices) also decreased. Currently, an acceleration in price growth can be observed, mainly due to rising fuel and transport prices. The average monthly wage in the Czech Republic in 2020 was CZK 35,611 - a 4.4\% increase compared to 2019, mainly due to an increase in salaries in education and the payment of remuneration in health care and social care. However, the dismissal of low-income employees as a result of the pandemic was also an indirect effect of wage growth. The growth rate of average real wages fell by $0.1 \%$ year-on-year.

Measures against the spread of coronavirus in 2020 also had a negative effect on foreign trade. According to preliminary results, the balance of foreign trade in goods reached CZK 71.1 billion, which represents a year-on-year decrease of CZK 41.6 billion. Exports decreased by $11 \%$ year-on-year, while imports decreased by $9.7 \%$. Among the EU27 countries, the balance of foreign trade in goods decreased by more than a third year-on-year during this period whereas among countries outside the EU27 it remained at almost the same level. From a commodity point of view, the overall declines in exports and imports since the beginning of the year are mainly due to the manufacturing industry.

\subsection{Government measures to crisis mitigation}

In 2020, the state budget deficit increased to CZK 367.4 billion, with more than CZK 200 billion being used to fight the pandemic. Another deficit budget totaling CZK 320 billion was approved for 2021. Programs to maintain employment (kurzarbait), compensation of wages, support for the self-employed, and the payment of nursing allowances at school closures have had significant budgetary implications. For example, as part of the compensatory bonus, CZK 29 billion was paid to support self-employed persons, partners of small companies, and citizens working on an agreement to perform work or an agreement to complete a job. In 2020 , the volume of fiscal measures related to the coronavirus crisis reached $2 \%$ of the GDP; for 2021 , it is forecast at about $0.4 \%$ of the GDP. Other measures to support the economy 
have included the abolition of the real estate acquisition tax, the suspension of the obligation to electronically record sales until the end of 2022, and the retroactive application of any tax loss reported for 2020 in the aggregate amount not exceeding CZK 30 million. The government also waived advances on road taxes for the 2021 tax period, introduced additional tax breaks related to personal and corporate income tax (extension of tax return deadlines), value added taxes (waiver of default interest and VAT waiver for respirators and more medical supplies), and real estate taxes. Public debt in the period under review exceeded CZK 2 trillion and reached $37.8 \%$ of the GDP.

\section{Conclusion}

The synchronized cyclical development of economies is one of the consequences of the strengthening of international economic cooperation and increasing globalization. The Czech economy, like most other countries in the world, is currently in an economic recession caused by the Covid-19 pandemic. The economic downturn in 2020 was the highest since the establishment of the Czech Republic. However, the recession could have been even deeper had fiscal policy not provided targeted support to the most affected sectors, industries, and professions. Mainly thanks to the fiscal policy, there has been only a slight increase in unemployment so far. The CNB responded to the looming risks by tripling rapid interest rate cuts and taking further steps to preserve financial stability. Although economic activity is expected to recover in the second half of 2021, the spread of the SARS-CoV-2 pandemic is still out of control, and there is uncertainty about the social and economic environment. Due to the nature of the economy (a small, open economy, the backbone of which is the automotive industry), the development of foreign markets is considered to be a key risk for further economic development. Obviously, the road to recovery will be neither easy nor fast. However, it is possible to observe a changing foundation of the functioning of the Czech economy and its individual subjects. Thus, there is hope and a challenge to use the ongoing pandemic in a positive direction. For the time being, the promise is a good condition of the domestic industry, especially for branches to which this crisis has brought new growth opportunities.

\section{Acknowledgements}

This work was supported by the Student Grant Competition of the University of Pardubice SGS_2021_022.

\section{References}

1. Broer, T., Hansen, Niels-Jakob H., Krusell, P., Oberg, E. (2019). The New Keynesian Transmission Mechanism: A Heterogeneous-Agent Perspective. Review of Economic Studies, 87(1), 77-101.

2. Cai, J., Li, N. (2019). Growth Through Inter-Sectoral Knowledge Linkages. Review of Economic Studies, 86 (5), 1827-1866.

3. Caligiuri, P., De Cieri, H., Minbaeva, D., Verbeke, A., Zimmermann, A. (2020). International HRM insights for navigating the COVID-19 pandemic: Implications for future research and practice. Journal of International Business Studies, 51 (5), 697-713.

4. CNB (2021, July 28). Czech National Bank: Zpráva o měnové politice III/2021. Available at : https://www.cnb.cz/export/sites/cnb/cs/menova-politika/.galleries/zpravy _o_inflaci/2021/2021_III/download/zoi_2021_III.pdf 
5. CSU (2021, July 20). Czech Statistical Office : Nejnovější ekonomické údaje. Available at: https://www.czso.cz/csu/czso/aktualniinformace

6. Deb, P., Furceri, D., Jonathan, D.O., Tawk, N. (2020). The Economic Effects of Covid19 Containment Measures. IMF working paper, Washington D.C.: IMF. https://www.imf.org/en/Publications/WP/Issues/2020/08/07/The-Economic-Effects-ofCOVID-19-Containment-Measures-49571

7. Dobrowolski, Z. (2020). After Covid-19: Reorientation of crisis management in crisis. Entrepreneurship and Sustainability Issues, 8(2), 799-810.

8. Falk, A., Becker, A., Dohmen, T., Enke, B., Huffman, D., Sunde, U. (2018). Global Evidence on Economic Preferences. Quarterly Journal of Economics, 133(4), 16451692.

9. Haberler, G. (1937). Prosperity and Depression. A Theoretical Analysis of Cyclical Movements.Economic Intelligence Service, League of Nations. Columbia University Press, New York City.

10. Klaus, V. (2020). Karanténa. Přežije naše svoboda éru pandemie? Institut Václava Klause.

11. Liu, D., Sun, W., Zhang, X. (2020). Is the Chinese Economy Well Positioned to Fight the COVID-19 Pandemic? the Financial Cycle Perspective. Emerging Markets Finance and Trade, 56(10), 2259-2276.

12. Mishra, M. K. (2020). The word after Covid-19 and its impact on global enonomy. Available

https://www.econstor.eu/bitstream/10419/215931/1/MKM\%20PAPER\%20FOR\%20C OVID.pdf

13. Mitchell, W. F. (2020). Debt and Deficits-A Modern Monetary Theory Perspective. Australian Economic Review, 53 (4), 566-576.

14. Petricevic, O., Teece, D. J. (2019). The structural reshaping of globalization: Implications for strategic sectors, profiting from innovation, and the multinational enterprise. Journal of International Business Studies, 50 (9), 1487-1512.

15. Rancan, A. (2020). From dynamics to stabilisation: Albert Ando and Franco Modigliani's contributions to the theory of economic growth and fluctuations (19591970). European Journal of The History of Economic Thought, 27(4), 635-660.

16. Smith, M., Yagan, D., Zidar, O., Zwick, E. (2019). Capitalists in The Twenty-First Century. Quarterly Journal of Economics, 134(4), 1675-1745.

17. Takahashi, S. (2020). Toward Reasonable Capitalism: The Role of John R. Commons's Price and Business Cycle Theories. Journal of Economic Issues, 54(2), 420-427. 